\title{
Commentary \\ Recent translational research: antiangiogenic therapy for breast cancer - where do we stand?
}

Kathy D Miller

Indiana University, Indianapolis, Indiana, USA

Correpsonding author: Kathy D Miller (e-mail: kathmill@iupui.edu)

Published: 18 March 2004

Breast Cancer Res 2004, 6:128-132 (DOI 10.1186/bcr782)

(c) 2004 BioMed Central Ltd

\begin{abstract}
The central importance of angiogenesis and our understanding of how new blood vessels are formed have led to the development of novel antiangiogenic therapies. Although the number of agents in development has grown exponentially, only one phase III trial in breast cancer has been completed. In that study the addition of bevacizumab to capecitabine did not extend the progression-free survival of patients with refractory disease as compared with capecitabine monotherapy. Early enthusiasm for antiangiogenic therapy must give way to clinical reality. Our challenge now is to exploit better the activity of antiangiogenic agents seen in the early clinical studies.
\end{abstract}

Keywords: angiogenesis, breast cancer, matrix metalloproteinase inhibitor, vascular endothelial growth factor

\section{Introduction}

Normal vasculature is quiescent in healthy adults with each endothelial cell dividing once every 10 years; active angiogenesis is required only for wound healing, endometrial proliferation, postlactational mammary gland involution, and pregnancy. In contrast, tissue remodeling and angiogenesis are crucial for the growth and metastasis of breast cancer, providing an attractive therapeutic target [1]. The central importance of angiogenesis and our understanding of how new blood vessels are formed have led to novel therapies designed to interrupt this process (see http://www.angiogenesis.org or http://cancernet.nci.nih.gov for a detailed list of agents in development). Although the number of ongoing phase I and II trials has grown rapidly, few have been reported in the peer-reviewed literature. To date only one phase III trial in breast cancer has been completed.

Antiangiogenic agents may be conceptually categorized as follows: endothelial toxins, which specifically target endothelial antigens; growth factor/receptor antagonists, which thwart signaling of proangiogenic growth factors; protease inhibitors, which interfere with the action of proteases that are critical for invasion; and natural inhibitors, which stimulate or mimic endogenous inhibitors of angiogenesis. In addition, several chemotherapeutic agents routinely employed in breast cancer treatment have true antiangiogenic activity. Clinical experience with representative agents in each category is reviewed.

\section{Endothelial toxins}

Disruption of endothelial cell chemotaxis and migration interferes with angiogenesis. The integrins, particularly $\alpha_{v} \beta_{3}$, provide critical attachment between the migrating endothelial cell and the extracellular matrix [2]; $\alpha_{v} \beta_{3}$ also localizes matrix metalloproteinase (MMP)-2 to the membrane of endothelial cells in the leading podosomes of new vessels, providing carefully targeted matrix destruction [3]. Vitaxin ${ }^{\mathrm{TM}}$ (Medimmune, Gaithersburg, MD, USA), a humanized monoclonal antibody recognizing $\alpha_{v} \beta_{3}$ (also known as the vitronectin receptor), inhibits endothelial proliferation in vitro and tumor growth in vivo [4]. In phase I trials Vitaxin ${ }^{\mathrm{TM}}$ was well tolerated but had limited activity $[5,6]$. Imaging tumor vasculature with $99 \mathrm{~m} T c$ Vitaxin $^{\mathrm{TM}}$ was unsuccessful in one pilot study including at least one patient with $\alpha_{v} \beta_{3}$ positive melanoma [7]. Phase II trials are ongoing. 


\section{Growth factor antagonists}

Angiogenesis requires stimulation of vascular endothelial cells through the release of angiogenic peptides, of which the vascular endothelial growth factor (VEGF) is the most potent. VEGF is a highly conserved, homodimeric, secreted, heparin-binding glycoprotein, the dominant isoform of which has a molecular weight of about $45 \mathrm{kDa}$ [8]. The biologic effects of VEGF are mediated through binding to one of three endothelial surface receptors VEGF-R1 (flt-1), VEGF-R2 (flk-1/kdr), and VEGF-R3; binding to the coreceptor neurophilin enhances signaling $[9,10]$. Although the VEGF receptors share considerable overlap in ligand binding, downstream effector interaction and biologic function, predominant actions have been identified. VEGF-R1 promotes differentiation and vascular maintenance [11]; VEGF-R2 induces endothelial cell mitogenesis and vascular permeability [12]; and VEGF-R3 stimulates lymphangiogenesis $[13,14]$.

Bevacizumab (Avastin ${ }^{\mathrm{TM}}$; Genentech, South San Francisco, CA, USA), a humanized monoclonal antibody directed against VEGF-A, inhibits growth of human tumors in animal models [15]. A phase II study of bevacizumab monotherapy conducted in 75 patients with previously treated metastatic breast cancer [16] reported a 9.3\% objective response rate with $17 \%$ of patients responding or stable at 22 weeks; four patients continued therapy without progression for over 12 months. Bevacizumab both alone and in combination with chemotherapy was well tolerated, with hypertension, proteinuria, thrombosis, and bleeding being the most commonly reported toxicities $[17,18]$.

A recently reported phase III trial randomly assigned 462 patients with anthracycline- and taxane-refractory disease to receive capcitabine with or without bevacizumab; the primary end-point was progression-free survival as assessed by an independent review facility. As expected, bevacizumab therapy induced hypertension, proteinuria, and minor mucosal bleeding but these toxicities were rarely severe; $12 \%$ of patients in each group discontinued therapy because of toxicity. Combination therapy significantly increased the response rates whether designated by the independent review facility $(9.1 \%$ versus $19.8 \%$; $P=0.001)$ or the local investigators $(19.1 \%$ versus $30.2 \%$; $P=0.006)$. Because many of the excess responses in the combination group were relatively short-lived, progression free survival was similar in both groups (4.17 versus 4.86 months; hazard ratio $=0.98$ ) [19]. Analysis of primary tumor samples for pathologic factors correlating with response to bevacizumab is ongoing. Initial results were limited by the small number of patients contributing samples but did not clearly identify a subset more likely to benefit [20]. A phase III trial (E2100) comparing paclitaxel, administered weekly for 3 out of 4 weeks, without or without bevacizumab in chemo-naïve patients with metastatic breast cancer is ongoing.

\section{Protease inhibitors}

Degradation of the basement membrane and surrounding stroma by the MMPs is crucial for direct tissue invasion and angiogenesis. MMP inhibitors significantly curtail primary breast tumor growth and establishment of metastases in preclinical xenograft models but they fail to shrink large, well established tumors [21]. Nonetheless, previous MMP inhibitors were tested largely in patients with metastatic disease. Whether administered as monotherapy or in combination with cytotoxic agents, the results were nearly uniform. MMP inhibitors had little activity in advanced disease, leading to termination of clinical development of several agents [22-26]. The most successful clinical application of MMP inhibitors was hypothesized to be in patients with micrometastatic disease. However, two adjuvant pilot trials demonstrated intolerable musculoskeletal toxicity $[27,28]$, making chronic administration of potentially therapeutic doses in the adjuvant setting implausible. The critical question, that regarding whether it is possible to separate inhibition of MMPs important in cancer progression from those whose inhibition produces joint toxicity, remains.

\section{Endogenous antiangiogenics}

A naturally occurring metabolite of estradiol, namely 2methoxyestradiol (2ME2), has a dual mechanism of action $[29,30]$ : it acts as an antiproliferative drug, exerting its effect directly on the tumor cell compartment, and as an antiangiogenic drug, acting on tumor vasculature. Recent studies suggested that $2 \mathrm{ME} 2$ uses the extrinsic pathway for induction of apoptosis. 2ME2 upregulates death receptor 5 expression in vitro and in vivo, rendering cells more sensitive to the death receptor 5 ligand, tumor necrosis factor-related apoptosis-inducing ligand (TRAIL). Inhibition of death receptor signaling by a dominantnegative Fas-associated death domain severely attenuates the 2ME2-induced apoptosis [31].

The first phase I trial of $2 \mathrm{ME} 2$ was conducted in patients with previously treated metastatic breast cancer [32]. 2ME2 was administered orally once (200-1000 mg/day; cohorts 1-5) or twice daily (200-800 mg every 12 hours; cohorts 6-9). Maximum tolerated dose was not reached. Metabolism was variable, with a half-life of approximately 10-12 hours. No objective responses were produced although prolonged disease stabilization was achieved in several patients. A second phase I study combined $2 \mathrm{ME} 2$ with docetaxel [33]. Treatment was well tolerated, with no detectable pharmacokinetic interaction. An overall response rate of $20 \%$ was reported; an additional $40 \%$ of patients had stable disease. In both phase I trials conversion to 2-methoxyestrone, an inactive metabolite, was significant, with 2-methoxyestrone concentrations generally 10-fold higher than 2ME2 levels. 2ME2 levels were substantially below those required for activity based on preclinical models. A new formulation with increased 
bioavailability and activity in animal models is expected to re-enter clinical trials in 2004.

\section{Antiangiogenic chemotherapy}

The intense interest in angiogenesis has also lead to a reexamination of the activity of many established cytotoxic agents. Several chemotherapeutic agents used routinely in breast cancer treatment have known antiangiogenic activity [34]. Maximal antiangiogenic activity typically requires prolonged exposure to low drug concentrations, exactly counter to maximum tolerated doses administered when optimal tumor cell kill is the goal. A number of recent reports confirm the importance of dose and schedule in preclinical models. In most models, the combination of low, frequent dose chemotherapy plus an agent that specifically targets the endothelial cell compartment controls tumor growth much more effectively than cytotoxic therapy alone [35-39]. These studies suggest that activated endothelial cells may be more sensitive, or even selectively sensitive, to protracted low-dose chemotherapy compared with other types of normal cells, thus creating a potential therapeutic window. Such selective sensitivity has been confirmed for several agents [40]. The antiangiogenic effect reported with low dose cyclophosphamide or microtubule agents may be due to induction of thrombospondin-1, a potent and endothelialspecific inhibitor of angiogenesis [41].

Thus far, few clinical trials have directly tested antiangiogenic schedules of chemotherapy. Nonetheless, the limited clinical evidence is intriguing. Remissions can be induced, albeit infrequently, in patients resistant to taxane therapy administered on an every 3-week basis by administering lower doses weekly [42]. E1199, a recently completed phase III adjuvant trial, compares paclitaxel with docetaxel weekly versus every 3 weeks and will determine the value of antiangiogenic taxane schedules.

The European Organization for Research and Treatment of Cancer studied two CMF (cyclophosphamide, methotrexate, and 5-fluorouracil) regimens [43]: a classic 28-day regimen incorporating daily oral cyclophosphamide for 14 days and a modified intravenous schedule with bolus cyclophosphamide every 3 weeks. Overall response rate and survival clearly favored the classic regimen. Although generally viewed as a test of dose intensity (the classic regimen delivered higher total doses of both cyclophosphamide and 5-fluoruracil), that study may also be considered a test of an antiangiogenic versus bolus schedule. Superiority of the classic regimen in the adjuvant setting has also been suggested in a retrospective study of two groups of patients treated at different institutions [44]. A phase II study of low dose methotrexate $(2.5 \mathrm{mg}$ twice daily for 2 days each week) and cyclophosphamide (50 $\mathrm{mg} /$ day) in patients with previously treated metastatic additional $13 \%$ of patients were stable for 6 months or more). Serum VEGF levels decreased in all patients remaining on therapy for at least 2 months but this did not correlate with response [45]. Several ongoing trials in both the metastatic and adjuvant setting are investigating this regimen further.

\section{Conclusion}

Our challenge now is to exploit better the activity of antiangiogenic agents seen in the early clinical studies. Thus far, antiangiogenic agents have been employed as general therapies given on a population basis, rather than as targeted therapies given to patients with a specific molecular phenotype. We must develop ways to select those patients who are most likely to benefit from each antiangiogenic agent. Perhaps even more importantly, the best time to intervene with an antiangiogenic agent may be earlier in the course of disease. Angiogenic pathways become more numerous and redundant as breast cancer progresses [46]. Given such redundancy, it is unlikely that inhibition of a single factor or pathway would produce a sustained clinical effect in patients with previously treated, highly refractory disease. As such, future trials must focus on patients with less advanced disease.

Early enthusiasm for antiangiogenic therapy, justified by impressive preclinical data, has given way to clinical reality genes are not proteins are not cells are not tissues are not organs are not mice are not patients. Although the early rampant enthusiasm has been dampened, cautious optimism rightly remains. It now seems certain that antiangiogenic therapies will be integrated into routine clinical practice. To believe otherwise would be to assume that angiogenesis is both biologically crucial yet therapeutically unimportant, which is an unlikely paradox.

\section{Competing interests}

Research supported by Genentech, AstraZeneca and Pfizer.

\section{References}

1. Folkman J: What is the evidence that tumors are angiogenesis dependent? J Natl Cancer Inst 1990, 82:4-6.

2. Brooks PC, Clark RA, Cheresh DA: Requirement of vascular integrin alpha $v$ beta 3 for angiogenesis. Science 1994, 264: 569-571.

3. Brooks PC, Stromblad S, Sanders LC, von Schalscha TL, Aimes RT, Stetler-Stevenson WG, Quigley JP, Cheresh DA: Localization of matrix metalloproteinase MMP-2 to the surface of invasive cells by interaction with integrin alpha v beta 3. Cell 1996, 85:683-693.

4. Brooks PC, Stromblad S, Klemke R, Visscher D, Sarkar FH, Cheresh DA: Antiintegrin alpha v beta 3 blocks human breast cancer growth and angiogenesis in human skin. J Clin Invest 1995, 96:1815-1822.

5. Gutheil JC, Campbell TN, Pierce PR, Watkins JD, Huse WD, Bodkin DJ, Hart J, Cheresh DA: Phase I study of vitaxin, an antiangiogenic humanized monoclonal antibody to vascular integrin $\alpha v \beta 3$ [abstract]. Proc Am Soc Clin Oncol 1998, 17:215a.

6. Patel SR, Jenkins J, Papadopolous N, Burgess MA, Plager C, Gutterman J, Benjamin RS: Pilot study of vitaxin: an angiogenesis inhibitor-in patients with advanced leiomyosarcomas. Cancer 2001, 92:1347-1348. 
7. Posey JA, Khazaeli MB, DelGrosso A, Saleh MN, Lin CY, Huse W, LoBuglio AF: A pilot trial of Vitaxin, a humanized anti-vitronectin receptor (anti alpha $v$ beta 3 ) antibody in patients with metastatic cancer. Cancer Biother Radiopharm 2001, 16: 125-132.

8. Ferrara N, Davis-Smyth T: The biology of vascular endothelial growth factor. Endocr Rev 1997, 18:4-25.

9. Neufeld G, Kessler O, Herzog Y: The interaction of Neuropilin-1 and Neuropilin-2 with tyrosine-kinase receptors for VEGF. Adv Exp Med Biol 2002, 515:81-90.

10. Soker S, Takashima S, Miao HQ, Neufeld G, Klagsbrun M: Neuropilin-1 is expressed by endothelial and tumor cells as an isoform-specific receptor for vascular endothelial growth factor. Cell 1998, 92:735-745

11. Cai J, Ahmad S, Jiang WG, Huang J, Kontos CD, Boulton M, Ahmed A: Activation of vascular endothelial growth factor receptor-1 sustains angiogenesis and $\mathrm{Bcl}-2$ expression via the phosphatidylinositol 3-kinase pathway in endothelial cells. Diabetes 2003, 52:2959-2968.

12. Brekken RA, Overholser JP, Stastny VA, Waltenberger J, Minna JD, Thorpe PE: Selective inhibition of vascular endothelial growth factor (VEGF) receptor 2 (KDR/Flk-1) activity by a monoclonal anti-VEGF antibody blocks tumor growth in mice. Cancer Res 2000, 60:5117-5124.

13. Skobe $M$, Hawighorst $T$, Jackson DG, Prevo $R$, Janes $L$, Velasco $\mathrm{P}$, Riccardi L, Alitalo K, Claffey K, Detmar M: Induction of tumor lymphangiogenesis by VEGF-C promotes breast cancer metastasis. Nat Med 2001, 7:192-198.

14. Kadambi A, Mouta Carreira C, Yun CO, Padera TP, Dolmans DE, Carmeliet $P$, Fukumura D, Jain RK: Vascular endothelial growth factor (VEGF)-C differentially affects tumor vascular function and leukocyte recruitment: role of VEGF-receptor 2 and host VEGF-A. Cancer Res 2001, 61:2404-2408.

15. Kim KJ, Li B, Winer J, Armanini M, Gillett N, Phillips HS, Ferrara N: Inhibition of vascular endothelial growth factor-induced angiogenesis suppresses tumour growth in vivo. Nature 1993, 362:841-844.

16. Cobleigh MA, Langmuir VK, Sledge GW, Miller KD, Haney L, Novotny WF, Reimann JD, Vassel A: A phase I/II dose-escalation trial of bevacizumab in previously treated metastatic breast cancer. Semin Oncol 2003, 30:117-124.

17. Gordon MS, Margolin K, Talpaz M, Sledge GW Jr, Holmgren E, Benjamin R, Stalter S, Shak S, Adelman D: Phase I safety and pharmacokinetic study of recombinant human anti- vascular endothelial growth factor in patients with advanced cancer. $J$ Clin Oncol 2001, 19:843-850.

18. Langmuir VK, Cobleigh MA, Herbst RS, Holmgren E, Hurwitz $\mathrm{H}$, Kabbinavar F, Miller K, Novotny W: Successful long-term therapy with bevacizumab (avastin) in solid tumors [abstract]. Proc Am Soc Clin Oncol 2002, 21:9a.

19. Miller KD, Rugo HS, Cobleigh MA, Marcom PK, Chap LI, Holmes FA, Fehrenbacher L, Overmoyer BA, Reimann JD, Vassel AV, Langmuir VK: Phase III trial of capecitabine (Xeloda) plus bevacizumab (Avastin) versus capecitabine alone in women with metastatic breast cancer previously treated with an anthracycline and a taxane [abstract]. Breast Cancer Res Treat 2002, 76:S37.

20. Hillan KJ, Koeppen HKW, Tobin P, Pham T, Landon TH, Miller KD, Holmes FA, Cobleigh MA, Reimann JD, Langmuir VK: The role of VEGF expression in response to bevacizumab plus capecitabine in metastatic breast cancer [abstract]. Proc Am Soc Clin Oncol 2003, 22:191.

21. Hidalgo M, Eckhardt SG: Development of matrix metalloproteinase inhibitors in cancer therapy. J Natl Cancer Inst 2001 93:178-193.

22. Bramhall SR, Schulz J, Nemunaitis J, Brown PD, Baillet M, Buckels JA: A double-blind placebo-controlled, randomised study comparing gemcitabine and marimastat with gemcitabine and placebo as first line therapy in patients with advanced pancreatic cancer. Br J Cancer 2002, 87:161-167.

23. Bramhall SR, Hallissey MT, Whiting J, Scholefield J, Tierney G, Stuart RC, Hawkins RE, McCulloch P, Maughan T, Brown PD, Baillet M, Fielding JW: Marimastat as maintenance therapy for patients with advanced gastric cancer: a randomised trial. $\mathrm{Br} J$ Cancer 2002, 86:1864-1870.

24. Sparano JA, Bernardo P, Gradishar WJ, Ingle JN, Zucker S, Davidson NE: Randomized phase II trial of marimastati versus placebo in patients with metastatic breast cancer who have responding or stable disease after first-line chemotherapy: an Eastern Cooperative Oncology Group trial (E2196) [abstract]. Proc Am Soc Clin Oncol 2002, 21:44a.

25. Erlichman C, Adjei AA, Alberts SR, Sloan JA, Goldberg RM, Pitot HC, Rubin J, Atherton PJ, Klee GG, Humphrey R: Phase I study of the matrix metalloproteinase inhibitor, BAY 12-9566. Ann Oncol 2001, 12:389-395.

26. Rudek MA, Figg WD, Dyer V, Dahut W, Turner ML, Steinberg SM, Liewehr DJ, Kohler DR, Pluda JM, Reed E: Phase I clinical trial of oral COL-3, a matrix metalloproteinase inhibitor, in patients with refractory metastatic cancer. J Clin Oncol 2001, 19:584-592.

27. Miller KD, Saphner TJ, Waterhouse DM, Chen T-T, Rush-Taylor A, Sparano JA, Wolff AC, Cobleigh MA, Galbraith S, Sledge GW: A randomized phase II feasibility trial of BMS-275291 in patients with early stage breast cancer. Clin Cancer Res, in press.

28. Miller KD, Gradishar W, Schuchter L, Sparano JA, Cobleigh M, Robert N, Rasmussen H, Sledge GW: A randomized phase II pilot trial of adjuvant marimastat in patients with early-stage breast cancer. Ann Oncol 2002, 13:1220-1224.

29. Fotsis T, Zhang Y, Pepper MS, Adlercreutz H, Montesano R, Nawroth PP, Schweigerer L: The endogenous oestrogen metabolite 2-methoxyoestradiol inhibits angiogenesis and suppresses tumour growth. Nature 1994, 368:237-239.

30. Klauber N, Parangi S, Flynn E, Hamel E, D'Amato RJ: Inhibition of angiogenesis and breast cancer in mice by the microtubule inhibitors 2-methoxyestradiol and Taxol. Cancer Res 1997, 57: 81-86.

31. LaVallee TM, Zhan XH, Johnson MS, Herbstritt CJ, Swartz G, Williams MS, Hembrough WA, Green SJ, Pribluda VS: 2methoxyestradiol up-regulates death receptor 5 and induces apoptosis through activation of the extrinsic pathway. Cancer Res 2003, 63:468-475.

32. Sledge Jr GW, Miller KD, Haney LG, Nguyen DD, Storniolo AM, Phillips EN, Pribluda V, Gubish ER: A phase I study of 2methoxyestradiol in patients with refractory metastatic breast cancer [abstract]. Proc Am Soc Clin Oncol 2002, 21:111a.

33. Miller KD, Murry DJ, Curry E, Haney LG, McClaskey N, Storniolo AM, Phillips E, Pribluda V, Gubish ER, Sledge Jr GW: A phase I study of 2-methoxyestradiol plus docetaxel in patients with metastatic breast cancer [abstract]. Proc Am Soc Clin Oncol 2002, 21:111a.

34. Miller K, Sweeney C, Sledge G: Redefining the target: chemotherapeutics as antiangiogenics. J Clin Oncol 2001, 19: 1195-1206.

35. Klement G, Huang P, Mayer B, Green SK, Man S, Bohlen P, Hicklin D, Kerbel RS: Differences in therapeutic indexes of combination metronomic chemotherapy and an anti-VEGFR-2 antibody in multidrug-resistant human breast cancer xenografts. Clin Cancer Res 2002, 8:221-232.

36. Takahashi N, Haba A, Matsuno F, Seon BK: Antiangiogenic therapy of established tumors in human skin/severe combined immunodeficiency mouse chimeras by anti-endoglin (CD105) monoclonal antibodies, and synergy between antiendoglin antibody and cyclophosphamide. Cancer Res 2001, 61:7846-7854.

37. Man S, Bocci G, Francia G, Green SK, Jothy S, Hanahan D, Bohlen P, Hicklin DJ, Bergers G, Kerbel RS: Antitumor effects in mice of low-dose (metronomic) cyclophosphamide administered continuously through the drinking water. Cancer Res 2002, 62:2731-2735.

38. Browder T, Butterfield CE, Kraling BM, Shi B, Marshall B, O'Reilly MS, Folkman J: Antiangiogenic scheduling of chemotherapy improves efficacy against experimental drug-resistant cancer. Cancer Res 2000, 60:1878-1886.

39. Klement G, Baruchel S, Rak J, Man S, Clark K, Hicklin DJ, Bohlen $\mathrm{P}$, Kerbel RS: Continuous low-dose therapy with vinblastine and VEGF receptor-2 antibody induces sustained tumor regression without overt toxicity. J Clin Invest 2000, 105:R15R24.

40. Bocci G, Nicolaou KC, Kerbel RS: Protracted low-dose effects on human endothelial cell proliferation and survival in vitro reveal a selective antiangiogenic window for various chemotherapeutic drugs. Cancer Res 2002, 62:6938-6943.

41. Bocci G, Francia G, Man S, Lawler J, Kerbel RS: Thrombospondin 1, a mediator of the antiangiogenic effects of low- 
dose metronomic chemotherapy. Proc Natl Acad Sci USA 2003, 100:12917-12922.

42. Seidman AD, Hudis CA, Albanel J, Tong W, Tepler I, Currie V, Moynahan ME, Theodoulou M, Gollub M, Baselga J, Norton L: Dose-dense therapy with weekly 1-hour paclitaxel infusions in the treatment of metastatic breast cancer. J Clin Oncol 1998, 16:3353-3361.

43. Engelsman E, Klijn JC, Rubens RD, Wildiers J, Beex LV, Nooij MA, Rotmensz N, Sylvester R: 'Classical' CMF versus a 3-weekly intravenous CMF schedule in postmenopausal patients with advanced breast cancer. Eur J Cancer 1991, 27:966-970.

44. Miles DW, Ryder K, Rubens RD, Leonard RC, Cameron DA: Comparison of 'three weekly' vs. 'four weekly' adjuvant CMF chemotherapy in operable breast cancer [abstract]. Breast Cancer Res Treat 2003, 82:S29.

45. Colleoni M, Rocca A, Sandri MT, Zorzino L, Masci G, Nole F, Peruzzotti G, Robertson C, Orlando L, Cinieri S, de BF, Viale G, Goldhirsch A: Low-dose oral methotrexate and cyclophosphamide in metastatic breast cancer: antitumor activity and correlation with vascular endothelial growth factor levels. Ann Oncol 2002, 13:73-80.

46. Relf M, LeJeune S, Scott PA, Fox S, Smith K, Leek R, Moghaddam A, Whitehouse R, Bicknell R, Harris AL: Expression of the angiogenic factors vascular endothelial cell growth factor, acidic and basic fibroblast growth factor, tumor growth factor beta1, platelet-derived endothelial cell growth factor, placenta growth factor, and pleiotrophin in human primary breast cancer and its relation to angiogenesis. Cancer Res 1997, 57: 963-969.

\section{Correspondence}

Kathy D Miller, Indiana University, 535 Barnhill Drive, RT-473, Indianapolis, IN 46202, USA. Tel: +1 317274 0920; fax: +1 317274

3646; e-mail: kathmill@iupui.edu 